weeks before endoscopy. Only six (17\%) of these patients presented with dyspepsia compared with 13 $(65 \%)$ of the 20 patients in the same age group who had not taken the drugs $\left(p<0.001, \chi^{2}\right.$ test $)$. The patients who had taken the drugs therefore constituted $81 \%$ (30/37) of those without dyspepsia. In the group aged 65-74 who had taken non-steroidal anti-inflammatory drugs the numbers with and without dyspepsia were similar. Overall, most of the patients who had taken the drugs presented with either bleeding or iron deficiency anaemia.

\section{Comment}

We suggest that non-steroidal anti-inflammatory drugs not only contribute to ulceration but also mask the pain that would normally lead to its diagnosis. This is a dangerous combination in elderly patients because it will cause them to present late with a serious complication such as bleeding or severe anaemia. Not only will this lead to an underestimate of the true incidence of ulceration in people aged 75 and over but it may also partially explain the worse prognosis of ulcers in the elderly. ${ }^{4}$

The higher incidence of gastric ulcer in women in our study was partly due to our having recruited more women overall, but it is possible that women are more susceptible to gastric ulceration or that they are more likely to take non-steroidal anti-inflammatory drugs.
Why do elderly patients taking these drugs not complain of dyspepsia? Although the elderly are known to complain of pain less than other people when they have, for instance, heart attacks or a perforated bowel, ${ }^{5}$ this would not explain the differences observed between our patients who had or had not taken non-steroidal anti-inflammatory drugs and yet belonged to the same age group. ${ }^{5}$ One possibility is that the drugs induce local or systemic analgesia; another is that they cause bleeding in a hitherto "silent" ulcer.

Our results indicate that the indiscriminate use of non-steroidal anti-inflammatory drugs in the elderly must be controlled. This is even more difficult now that ibuprofen, like aspirin, is available without prescription.

We thank the many colleagues who allowed us to study their patients.

1 Lanza FL, Royer GL, Nelson RS, Chen TT, Seckman CE, Rack MF. The effects of ibuprofen, aspirin, naproxen, and placebo on the gastric mucosa of effects of ibuprofen, aspirin, naproxen, and placel

2 Clinch D, Banerjee AK, Levy DW, Ostick G, Feracher EB. Non-steroidal anti-inflammatory drugs and peptic ulceration. $\mathcal{f} R$ Coll Physicians Lond anti-inflammatory

3 Somerville K, Faulkner G, Langman $M$. Non-steroidal anti-inflammatory drugs and bleeding peptic ulcer. Lancet 1986;i:462-4.

4 Armstrong CP, Blower AL. Non-steroidal anti-inflammatory drugs and life threatening complications of peptic ulcer. Gut 1987;28:527-32.

5 Coleman JA, Denham MJ. Perforation of peptic ulcer in the elderly. Age Ageing 1980;9:257-61.

(Accepted 22 June 1988)

\title{
Increased bacterial binding to respiratory epithelial cells in vitamin A deficiency
}

\section{R K Chandra}

Memorial University of Newfoundland, Health Sciences Centre, St John's, Newfoundland A1B 3V6, Canada

R K Chandra, $\operatorname{FRCP}(\mathrm{C})$, professor of paediatric research, medicine, and biochemistry
Malnutrition is an important risk factor for infection. ${ }^{1}$ Vitamin A deficiency is common in economically deprived populations, including those in industrialised countries. It is associated with a high incidence of infection, particularly respiratory disease, and contributes considerably to childhood morbidity and mortality. ${ }^{2}$ It occurs in $30-75 \%$ of all patients with protein and energy malnutrition and enhances the overall risk of death. Vitamin A has an important role in regulating immunocompetence ${ }^{3}$ : impaired immune responses were observed in people with vitamin A deficiency as well as in deprived laboratory animals.

Little is known about the barrier function of epithelial cells in vitamin A deficiency. Bacteria must adhere to mucosal cells before systemic invasion begins. The alterations in the morphology and turnover of

Clinical data and bacterial binding to epithelial cells

\begin{tabular}{|c|c|c|c|}
\hline & $\begin{array}{l}\text { Children without } \\
\text { vitamin A } \\
\text { deficiency } \\
\text { (group 1) }\end{array}$ & $\begin{array}{c}\text { Children with } \\
\text { mild vitamin A } \\
\text { deficiency } \\
\text { (group 2) }\end{array}$ & $\begin{array}{c}\text { Children with } \\
\text { moderately severe } \\
\text { vitamin A deficiency } \\
\text { (group 3) }\end{array}$ \\
\hline No in group & 14 & 10 & 12 \\
\hline Mean (SE) age (months) & $22(3)$ & $24(4)$ & $20(3)$ \\
\hline No of boys:girls & $8: 6$ & $6: 4$ & $7: 5$ \\
\hline \multicolumn{4}{|l|}{ Serum retinol $(\mu \mathrm{mol} / \mathrm{l})$ : } \\
\hline Mean $(\mathrm{SE})$ & $2 \cdot 2(0 \cdot 3)^{\star}$ & $1 \cdot 1(0 \cdot 1)^{\star}$ & $0 \cdot 4(0 \cdot 1)^{\star}$ \\
\hline Range & $1 \cdot 4-3 \cdot 4$ & $0 \cdot 7-1 \cdot 4$ & $0 \cdot 1-0 \cdot 7$ \\
\hline Mean (SE) dietary vitamin A intake (retinol & $321(44)^{\star}$ & $201(29)^{\star}$ & $186(22)^{\star}$ \\
\hline \multicolumn{4}{|l|}{ No with: } \\
\hline Xerophthalmia & & 4 & 9 \\
\hline Bitot's spots & & 2 & 6 \\
\hline Corneal opacity & & 1 & 4 \\
\hline Mean (SE) weight-for-height ( $\%$ of standard) & $81(4)$ & $77(3)$ & $74(5)$ \\
\hline Mean (SE) no of bacteria/epithelial cell & $4 \cdot 8(0 \cdot 6)^{\star}$ & $7 \cdot 9(1 \cdot 0)^{\star}$ & $10 \cdot 3(0 \cdot 8)^{\star}$ \\
\hline
\end{tabular}

${ }^{\star} \mathrm{p}<0.01$. respiratory epithelial cells in vitamin A deficiency ${ }^{4}$ suggest that the ability of mucosal cells to prevent penetration by pathogenic bacteria is compromised. I report the binding of bacteria to nasopharyngeal epithelial cells in children with vitamin A deficiency.

\section{Subjects, methods, and results}

I studied three groups of Indian children. Group 1 comprised apparently healthy children without ophthalmological evidence of vitamin A deficiency whose plasma retinol concentration was $>1.4 \mu \mathrm{mol} / 1$. Group 2 comprised children with mild vitamin A deficiency and a plasma retinol concentration of 0.7 $1.4 \mu \mathrm{mol} / 1$. Group 3 comprised children with eye signs of moderately severe vitamin A deficiency and a plasma retinol concentration $<0.7 \mu \mathrm{mol} / \mathrm{l}$. Current or recent respiratory infection was ruled out by clinical evidence and estimation of $\mathrm{C}$ reactive protein concentrations. Three 24 hour dietary intakes were recorded on three days by a dietitian and plasma retinol concentration was measured by high performance liquid chromatography. The table gives the demographic and nutritional data.

Nasopharyngeal secretions were obtained by injection of $0.5 \mathrm{ml}$ saline through a soft nasal catheter with immediate suction. This procedure was repeated three times. The epithelial cells were washed and counted and the concentration adjusted to $0.025 \times 10^{9}$ cells $/ 1$. The average viability of the cells was $72 \%$. A clinical isolate of Klebsiella pneumoniae was grown in broth culture containing amino acid mixture labelled with $0.93 \mathrm{MBq}$ carbon-14. After 15 hours the microorganisms were washed to remove excess free radioactivity and resuspended to a concentration of $5 \times 10^{\circ}$ bacteria/l. The amount of radioactivity remaining was related to the number of bacteria as determined by the pour plate method. The bacterial adherence technique of Niederman et al $l^{5}$ was followed with slight modification, 200 bacteria per cell being used. Differences between group means were analysed by Student's $t$ test.

The number of bacteria adhering to nasopharyngeal 
epithelial cells was significantly higher in the samples from the children deficient in vitamin A (table). Vitamin A intake was less than the recommended allowance of 400 retinol equivalents/day in all three groups; the average intake was lower in groups 2 and 3 than group 1. Groups 2 and 3 had a lower weight for height than group 1, but the differences were not significant.

\section{Comment}

The increased bacterial adherence to epithelial cells found in children with vitamin A deficiency provides evidence for an additional factor that can contribute to the increased risk of infection in this disease. Nutritional deficiencies impair several host defence mechanisms, but much of the work done in the past 20 years focused on immune responses rather than physical barriers. ${ }^{13}$

This study shows that respiratory epithelial surfaces of vitamin A deficient subjects may permit increased colonisation and thus allow penetration of mucosa, leading to systemic infection. Various barriers contribute to local defence on mucosal surfaces, including mucus, glycocalix, cilia, secretory IgA, neutrophils, macrophages, and $\mathrm{T}$ lymphocytes. It is not clear which aspects of this barrier are affected by vitamin A deficiency. A prospective study should be done to correlate bacterial adherence to epithelial cells with morbidity. A firm cause and effect relation would be established if vitamin A supplements were found to correct the abnormal bacterial adherence.

1 Chandra RK. Nutrition, immunity, and infection. Present knowledge and future directions. Lancet 1983; ; 688-91.

2 Sommer A, Tarwotjo I, Hussaini G, Susanto D. Increased mortality in children with mild vitamin A deficiency. Lancet 1983;ii:585-8.

Vyas D, Chandra RK. Vitamin A and immunocompetence. In: Watson RR, ed. Nutrition, disease resistance and immune function. New York: Marcel Dekker, 1984:325-44.

4 Wong YC, Buck RC. An electron microscopic study of the metaplasia of the rat tracheal epithelium in vitamin A deficiency. Lab Invest 1971;24:55-66.

Niederman MS, Rafferty TD, SasakiCT, Merrill WW, Matthay RA, Reynolds HY Co HY. Comparison of bacterial adherence to ciliated and squamous epithelia cells obtained from the human respiratory tract. Am Rev Respir Dis
$1983 ; 127: 85-90$.

(Accepted 3 fune 1988

\section{Risk to Metropolitan police officers from exposure to hepatitis B}

\author{
Jan Welch, Anthea J Tilzey, John Bertrand, \\ E C A Bott, J E Banatvala
}

Department of Virology, United Medical and Dental Schools of Guy's and St Thomas's Hospitals, St Thomas's Campus, London SE1 7EH Jan Welch, MRCP, senior registrar

Anthea J Tilzey, MRCP, senior registrar

John Bertrand, FIMLS, senior chief medical laboratory scientific officer

J E Banatvala, FRCPATH, professor

Metropolitan Police, Medical Branch, New Scotland Yard, London SW1H 0BG

E C A Bott, FRCP, chief medical officer

Correspondence and reprint requests to: Professor Banatvala.
Since 1981 St Thomas's Hospital has provided a service to members of the Metropolitan police who have been in incidents conferring a risk of exposure to hepatitis B virus. We describe our experience in assessing this risk and provide recommendations for immunising police officers.

\section{Subjects, methods, and results}

In the procedure followed by the police after an incident conferring a risk of hepatitis police surgeons take a blood sample from the officer and, whenever feasible, from the person suspected of having hepatitis (the contact). The officer then attends the virology department, where a doctor assesses his risk and obtains details of the incident and the risk factors.

Samples from officers and, when available, the contact were tested for hepatitis B surface antigen ( $\mathrm{HBsAg}$ ); those found positive were tested for hepatitis $\mathrm{B}$ e antigen ( $\mathrm{HBeAg})$ and antibody. All samples from officers that were negative for $\mathrm{HBsAg}$ were tested for antibody to HBsAg. (If there had been a considerable delay between the incident and presentation specimens from contacts were initially tested with a modified
Hepatest II (Wellcome), which gave results within one hour.) If the suspect was positive for $\mathrm{HBsAg}$ the officer was offered hepatitis B immunoglobulin if his eyes or fresh cuts had been contaminated by blood or saliva or after a needlestick incident. When hepatitis B vaccine became widely available it was recommended in addition. A second dose of immunoglobulin was given one month later unless the contact had antibody to $\mathrm{HBeAg}$ or hepatitis B vaccination had been started within one week of the incident. When blood from the contact was not available offering immunoglobulin depended on the risk and on the availability of immunoglobulin.

During 1981-6, 503 incidents with a risk of hepatitis were reported in 793 officers, of whom 248 (31\%) were given hepatitis B immunoglobulin. The number of officers seen increased considerably, from 46 in 1981 to 187 in 1986. During 1983-6, 33 of 198 samples tested from suspects were positive for $\mathrm{HBsAg}$ and half of those were also positive for $\mathrm{HBeAg}$. Most contacts (table) were drug abusers or dealers, whereas the most frequent type of incident was contact with a bleeding person. Altogether $12 \%$ of officers attended because they had arrested a person who then claimed to be a carrier. Other contacts included prostitutes, vagrants, transvestites, and corpses. No officers were found to be HBsAg positive and only three (1\%) of 425 tested had evidence of past infection. No subsequent attacks of hepatitis B were identified in any of these officers.

\section{Comment}

Hepatitis B can be transmitted easily through parenteral contact with infected blood and secretions, and such cases occur in police officers. ${ }^{1}$ The number

Details of contacts involved in incidents conferring risk of exposure to hepatitis B to Metropolitan police officers, 1983-6

\begin{tabular}{|c|c|c|c|c|c|c|c|c|c|c|}
\hline & \multicolumn{5}{|c|}{ Contact } & \multicolumn{5}{|c|}{ Incident } \\
\hline & $\begin{array}{c}\text { Male } \\
\text { homosexual }\end{array}$ & $\begin{array}{c}\text { Drug } \\
\text { addict or } \\
\text { dealer }\end{array}$ & $\begin{array}{c}\text { Homosexual } \\
\text { drug } \\
\text { addict }\end{array}$ & $\begin{array}{l}\text { Ethnic origin } \\
\text { suggested high } \\
\text { risk of } \\
\text { carriage of } \\
\text { hepatitis B virus }\end{array}$ & $\begin{array}{l}\text { Not known } \\
\text { or other }\end{array}$ & $\begin{array}{c}\text { Minimal } \\
\text { contact } \\
\text { but } \\
\text { officer } \\
\text { concerned }\end{array}$ & $\begin{array}{c}\text { Bleeding } \\
\text { person }\end{array}$ & $\begin{array}{c}\text { Aggressive } \\
\text { contact } \\
\text { (contact not } \\
\text { bleeding) } \\
\end{array}$ & $\begin{array}{c}\text { Needlestick } \\
\text { injury }\end{array}$ & Other \\
\hline $\begin{array}{l}1983 \\
1984 \\
1985 \\
1986\end{array}$ & $\begin{array}{r}1 \\
4 \\
4 \\
10\end{array}$ & $\begin{array}{r}72 \\
54 \\
73 \\
100\end{array}$ & $\begin{array}{l}3 \\
2 \\
3\end{array}$ & $\begin{array}{l}2 \\
1\end{array}$ & $\begin{array}{l}20 \\
12 \\
16 \\
22\end{array}$ & $\begin{array}{l}13 \\
10 \\
11 \\
13\end{array}$ & $\begin{array}{l}24 \\
19 \\
34 \\
50\end{array}$ & $\begin{array}{l}16 \\
19 \\
20 \\
41\end{array}$ & $\begin{array}{l}38 \\
17 \\
27 \\
23\end{array}$ & $\begin{array}{l}5 \\
3 \\
4 \\
8\end{array}$ \\
\hline Total (\%) & $15(4)$ & $299(76)$ & $8(2)$ & $3(1)$ & $70(18)$ & $47(12)$ & $127(32)$ & $96(24)$ & $105(27)$ & $20(5)$ \\
\hline
\end{tabular}

